\title{
Reactions of 3,5-Dimethyl-1,2,4,3,5-trithiadiborolane with Secondary Amines: Formation of Diorganylamino(sulfhydryl)boranes*
}

\author{
Heinrich Nöth and Tilman Taeger \\ Department of Chemistry and Biochemistry, University of Munich, Butenandtstr. 5-13, \\ 81377 München, Germany \\ Reprint requests to Prof. Dr. H. Nöth. E-mail: H.Noeth@1rz.uni-muenchen.de \\ Z. Naturforsch. 2010, 65b, 173 - 177; received September 15, 2009
}

The $1: 1$ reaction of 3,5-dimethyl-1,2,4,3,5-trithiadiborolane, $\mathbf{3}$, with dimethylamine in diethyl ether yielded a mixture of compounds from which only $\mathrm{MeB}\left(\mathrm{NMe}_{2}\right) \mathrm{SH}, 7$, could be separated. In the 1:2 reaction, insoluble $\mathrm{Me}_{2} \mathrm{NH}\left(\mathrm{MeB}\left(\mathrm{S}_{2}\right)_{2} \mathrm{BMe}\right) \mathrm{HNMe}_{2}, \mathbf{1 0}$, could be isolated besides 7 and small amounts of $\mathrm{MeB}\left(\mathrm{NMe}_{2}\right)_{2}$. In the presence of $\mathrm{NMe}_{3}$ the bis(methyl-dimethylamino-boryl)sulfide, 7 was obtained in good yield. Replacement of $\mathrm{HNMe}_{2}$ by $N$-methylaniline or piperidine led to the corresponding amino(methyl)sulfhydrido boranes $\mathrm{R}_{2} \mathrm{~N}(\mathrm{MeB}) \mathrm{SH}$ in moderate yields. $t \mathrm{BuNH}(\mathrm{MeB}) \mathrm{SH}$ results in $61 \%$ yield from the treatment of $t \mathrm{Bu}_{2} \mathrm{~B}_{2} \mathrm{~S}_{3}$ with $t \mathrm{BuNH}_{2}$ in a $1: 1$ ratio.

Key words: Diorganylamino(sulfhydryl)methylboranes,

Dimeric Dimethylamino(sulfhydryl)methylborane

\section{Introduction}

It is well known that the five-membered $1,2,4,3,5$ trithiadiborolanes $\mathrm{R}_{2} \mathrm{~B}_{2} \mathrm{~S}_{3}, \mathbf{1}[1,2]$, are more reactive than the five-membered triazadiborolidines $\left(\mathrm{R}_{2} \mathrm{~B}\right)_{2}\left(\mathrm{NR}^{\prime}\right)_{3}$ [3], and this corresponds with the higher reactivity of the six-membered 1,3,5,2,4,6 trithiatriboranes $(\mathrm{RB}=\mathrm{S})_{3}[1]$ compared to borazines $\left(\mathrm{RB}=\mathrm{NR}^{\prime}\right)_{3}$ $[4,5]$. This difference in chemical behavior is due to the stronger $\mathrm{B}-\mathrm{N}$ bonds compared with $\mathrm{B}-\mathrm{S}$ bonds. BN $\pi$-bonding in borazines [4-7] makes the boron atoms less electrophilic than the boron atoms in trithiatriboranes. Whether the $\mathrm{B}-\mathrm{S}$ bonds of $\mathrm{B}_{n} \mathrm{~S}_{m}$ heterocycles have $\pi$-bond character is still a matter of debate [8]. Thus, the B-S bond lengths in bis(dithiaborolanyl)sulfide points to a small $\pi$-bond contribution, as shown by significantly different B-S bond lengths: $1.788 \AA$ for the ring $\mathrm{B}-\mathrm{S}$ bonds and $1.812 \AA$ for the bridge $\mathrm{B}-\mathrm{S}$ bonds [9]. The former are also shorter than the $\mathrm{B}-\mathrm{S}$ bonds in $\mathrm{B}(\mathrm{SR})_{3}$ with $1.805 \AA$ [10], which indicates some $\pi$-bond character in the $\mathrm{B}-\mathrm{S}-\mathrm{B}$ bond [8].

In the case of $\mathrm{Br}_{2} \mathrm{~B}_{2} \mathrm{~S}_{3}$ the $\mathrm{B}-\mathrm{Br}$ bond is generally more reactive than the $\mathrm{B}-\mathrm{S}$ bond, as shown by reactions with electrophilic borane deriva-

* Contribution to the Chemistry of Boron 274. For Contribution 273, see Z. Naturforsch. 2009, 64b, 1090. tives $\mathrm{BY}_{3}\left(\mathrm{Y}=\mathrm{Hal}, \mathrm{OR}, \mathrm{NR}_{2} \mathrm{R}\right)$ which yield trithiadiborolanes $\mathrm{Y}_{2} \mathrm{~B}_{2} \mathrm{~S}_{3}$ by $\mathrm{Br} / \mathrm{Y}$ exchange $[11,12]$. Aminolysis of $\mathrm{Br}_{2} \mathrm{~B}_{2} \mathrm{~S}_{3}$ leads to 3,5-diamino-trithiadiborolanes (Eq. 1) [13], and diorganylaminotrimethylsilanes react with $\mathrm{Br}_{2} \mathrm{~B}_{2} \mathrm{~S}_{3}$ to generate the corresponding bis(diorganylamino)-trithiadiborolanes [14]. However, reactions of 3,5-diorganyltrithiadiborolanes with primary amines can lead to diorganyl-dithiadiborazolines, 2, as shown in Eq. 1 [15]. However, the reaction of $\mathrm{Me}_{2} \mathrm{~B}_{2} \mathrm{~S}_{3}, \mathbf{3}$, with primary amines is much more complex depending on the reaction conditions, the molar ratio of $\mathrm{Me}_{2} \mathrm{~B}_{2} \mathrm{~S}_{3}: \mathrm{RNH}_{2}$ as well as on the steric requirements of the primary amines used (Scheme 1) [16].

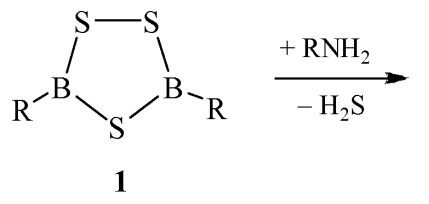<smiles>[R]B1SSB([R])N1[R]</smiles>

\section{Results and Discussion}

It was, therefore, of interest to study the reaction of $\mathrm{Me}_{2} \mathrm{~B}_{2} \mathrm{~S}_{3}$ with secondary amines because neither borazines nor thiaborazines can form only non-cyclic dialkylamino-sulfhydryl-methylboranes. It was also expected that the $1: 1$ reaction with secondary amines 


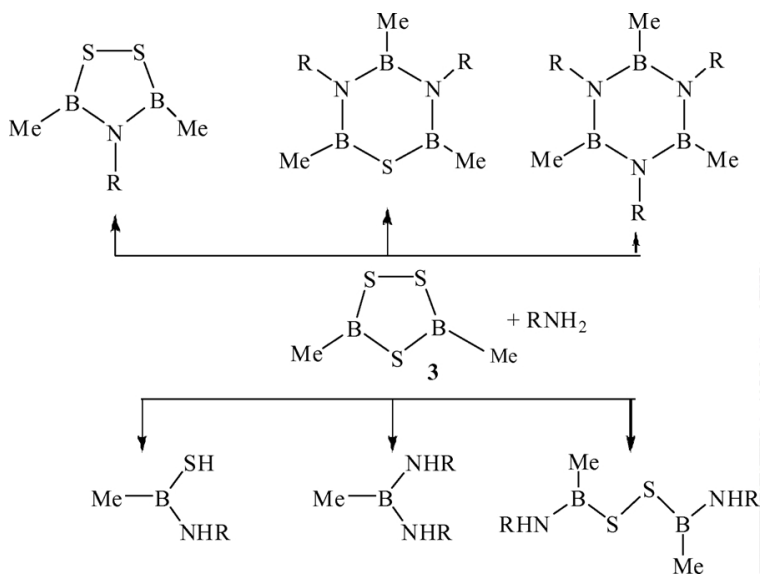

Scheme 1.

shows whether the B-S-B unit is affected by ring opening, or the B-S-S-B unit, as proposed in Eqs. 2 and 3 .
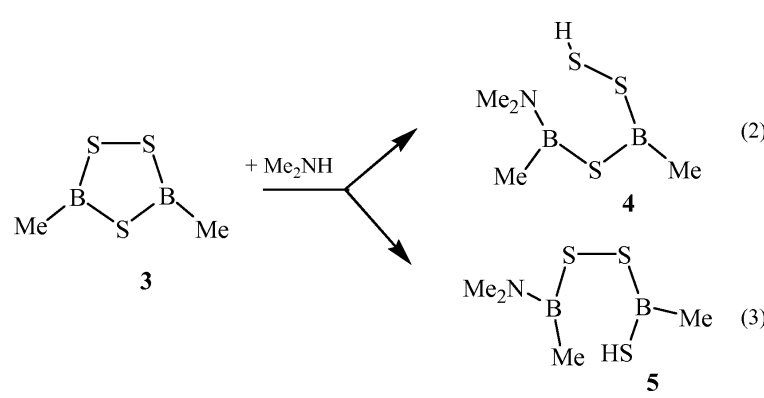

\section{Reactions with dimethylamine}

The reaction of $\mathbf{3}$ with dimethylamine in diethyl ether at $-70{ }^{\circ} \mathrm{C}$ led to an insoluble product which dissolved almost completely at r.t. After filtration three ${ }^{1} \mathrm{H}$ NMR signals were recorded from the filtrate at $\delta=0.45,0.88$ and 2.56 (d) ppm (ratio $1: 1: 2$ ) which indicated the presence of either a $1: 1$ or a $1: 2$ dimethylamine adduct of 3 (11). It is unlikely that the solvolysis products $\mathbf{4}$ or $\mathbf{5}$ are formed, because we found no signal for an SH group. After removal of most of the solvent a sticky solid remained. Distillation at $70{ }^{\circ} \mathrm{C} / 10^{-3}$ Torr yielded an oily product that crystallized on standing. Its ${ }^{11} \mathrm{~B}$ NMR spectrum showed three signals at $\delta=70.7$ (50\%), 42.3 $(25 \%)$ and $8 \mathrm{ppm}(25 \%)$. These signals can be assigned to 3, $\mathrm{Me}_{2} \mathrm{~N}(\mathrm{Me}) \mathrm{BSH}, \mathbf{7}$, and its dimer. Further fractionation at $98{ }^{\circ} \mathrm{C} / 10^{-3}$ Torr led to a solid compound of m.p. $84{ }^{\circ} \mathrm{C}$. This compound is not dimeric $4(=\mathbf{8})$, but its isomer $\mathbf{1 0}$ because the IR spectrum

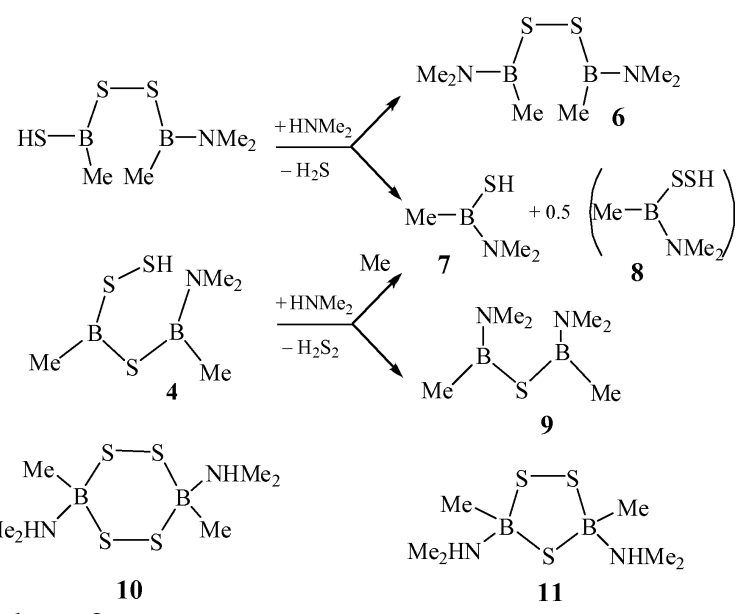

Scheme 2.

did not show SH stretching bands in contrast to an NH band (v. i.). Scheme 2 shows possible and observed reactions.

A somewhat less complex course can be expected for the reaction of 3 with $\mathrm{Me}_{2} \mathrm{NH}$ in a $1: 2$ ratio because the $\mathrm{B}-\mathrm{S}$ bonds should be cleaved with formation of $\mathrm{H}_{2} \mathrm{~S}$ or $\mathrm{H}_{2} \mathrm{~S}_{2}$ (or $\mathrm{H}_{2}$ and sulfur). Indeed, now the main product is $\mathrm{MeB}\left(\mathrm{NMe}_{2}\right) \mathrm{SH}, 7$ (Scheme 2). In addition, a small amount of $\mathrm{MeB}\left(\mathrm{NMe}_{2}\right)_{2}$ could also be detected in the ${ }^{11} \mathrm{~B}$ NMR spectrum. The solid that precipitated at the beginning of the reaction proved to be $\left[\mathrm{Me}_{2} \mathrm{NH}(\mathrm{Me}) \mathrm{BSS}\right]_{2}, \mathbf{1 0}$, but not its isomer $\mathbf{8}$ because its IR spectrum shows an $\mathrm{NH}$ band at $3210 \mathrm{~cm}^{-1}$, but no $\mathrm{SH}$ band around $2620 \mathrm{~cm}^{-1}$. Its structure was also characterized by its NMR and mass spectra. Heating the precipitate to $100{ }^{\circ} \mathrm{C}$ in vacuo produced small quantities of a solid condensate which reacted rapidly with a solution of bromine in $\mathrm{CH}_{2} \mathrm{Cl}_{2}$. This indicates the presence of $\mathrm{B}-\mathrm{S}$ bonds in this material. The solid residue proved to be pure 10 . It melts at $160-162{ }^{\circ} \mathrm{C}$.

The formation of gel-like material from the clear condensates points to the formation of associates. This behavior is well known for $\mathrm{Me}_{2} \mathrm{~B}-\mathrm{S}-\mathrm{BMe}_{2}$ [17]. The ${ }^{11} \mathrm{~B}$ NMR spectrum of a freshly prepared clear condensate showed a signal at $42.2 \mathrm{ppm}$ for 7 , and at $11 \mathrm{ppm}$ for a tetra-coordinated boron atom. The latter most likely results from the $\mathrm{Me}_{2} \mathrm{NH}$ adduct $\mathbf{1 1}$ of the trithiadiborolane 3 . The aminolysis of the reaction of 3 with dimethylamine at $-10{ }^{\circ} \mathrm{C}$ led after a short reaction time $(2 \mathrm{~h})$, to a filtrate with two ${ }^{11} \mathrm{~B}$ NMR signals at 42 and $11 \mathrm{ppm}$, in a ratio of $10: 1$. Within $2 \mathrm{~h}$ the less intense signal at $11 \mathrm{ppm}$ became more and more intense until the ratio was about $1: 1$. In addition, a new signal appeared for a tetra-coordinated ${ }^{11} \mathrm{~B}$ atom 
<smiles>CN1B([AsH])N(C)C1(C)S</smiles>

12

at $3 \mathrm{ppm}$, which may be due to the four-membered ring compound 12.

In order to prevent the formation of products carrying $\mathrm{SH}$ groups, trimethylamine was added to the reaction mixture of $\mathrm{Me}_{2} \mathrm{NH}$ and 3. Astonishingly, the trimethylamine could be completely recovered in vасио. Nevertheless it had an important influence on the course of the reaction because the ratio of 5 to $\mathrm{MeB}\left(\mathrm{NMe}_{2}\right)_{2}$ was now $4: 1$, corresponding to a $54 \%$ yield of $\mathbf{5}$. The yield of the insoluble $\mathbf{1 0}$ rose to $95 \%$.This, however, gives no clear evidence whether the $\mathrm{B}-\mathrm{S}-\mathrm{B}$ or the $\mathrm{B}-\mathrm{S}-\mathrm{S}-\mathrm{B}$ groups are preferentially attacked by dimethylamine. Compounds 6 and 9 could not be isolated or detected spectroscopically.

\section{Reaction of $\mathrm{R}_{2} \mathrm{~B}_{2} \mathrm{~S}_{3}$ with $\mathrm{N}$-methylaniline, piperidine and tert-butylamine}

The addition of $N$-methylaniline to a diethyl ether solution of $\mathbf{3}$ at $-70{ }^{\circ} \mathrm{C}$ resulted in a precipitate which dissolved on heating the mixture to reflux. On cooling, a solid formed, and distillation of the filtrate yielded $\mathrm{MeB}(\mathrm{NMePh}) \mathrm{SH}$ in $21 \%$ yield. Similarly, the reaction of 3 with piperidine in a 1:2 ratio led to the isolation of $\mathrm{MeB}$ (pip)SH in $32 \%$ yield. It was, however, surprising that the reaction of $t \mathrm{BuNH}_{2}$ with $t \mathrm{Bu}_{2} \mathrm{~B}_{2} \mathrm{~S}_{3}$ yielded $t \mathrm{BuB}(\mathrm{NH} t \mathrm{Bu}) \mathrm{SH}$ in $61 \%$ yield, as shown in Eq. 4 . This demonstrates that the bulky tert-butyl amine reacts like secondary amines with the sterically shielded boron atoms of $(t \mathrm{Bu})_{2} \mathrm{~B}_{2} \mathrm{~S}_{3}$.

$$
\begin{aligned}
& t \mathrm{Bu}_{2} \mathrm{~B}_{2} \mathrm{~S}_{3}+2 \mathrm{H}_{2} \mathrm{~N} t \mathrm{Bu} \\
& \rightarrow 2 t \mathrm{BuB}(\mathrm{NH} t \mathrm{Bu}) \mathrm{SH}+1 / 8 \mathrm{~S}_{8}
\end{aligned}
$$

\section{Conclusions}

The reaction of $\mathrm{Me}_{2} \mathrm{~B}_{2} \mathrm{~S}_{3}$ with secondary amines leads, like the reaction of $\mathrm{Me}_{2} \mathrm{~B}_{2} \mathrm{~S}_{3}$ with primary amines, to various products by ring opening reactions. However, it could not be proved whether the boronsulfur bonds of the B-S-B or the B-S-S-B group are preferentially attacked, because $\mathrm{MeB}\left(\mathrm{NMe}_{2}\right) \mathrm{SH}$ and $\left[\mathrm{MeB}\left(\mathrm{NHMe}_{2}\right) \mathrm{SS}\right]_{2}$ are formed. In case of sterically more demanding secondary amines the main products are of the type $\mathrm{MeB}\left(\mathrm{NR}_{2}\right) \mathrm{SH}$. Moreover, the trithiadiborolane $(t \mathrm{Bu})_{2} \mathrm{~B}_{2} \mathrm{~S}_{3}$ reacts with $t \mathrm{BuNH}_{2}$, as shown in Eq. 4 , similar to the secondary amines. This shows that steric effects are controlling the aminolysis of the $\mathrm{R}_{2} \mathrm{~B}_{2} \mathrm{~S}_{3}$ heterocycle.

\section{Experimental Section}

All reactions were performed under anhydrous conditions using Schlenk techniques under argon gas. Amines were of high-purity commercial quality. $\mathrm{Me}_{2} \mathrm{~B}_{2} \mathrm{~S}_{3}$ was prepared according to the literature [13]. Solvents were dried by standard procedures and distilled prior to use. Elemental analyses were conducted in the Microanalytical Laboratory of the Department. ${ }^{1} \mathrm{H}$ and ${ }^{11} \mathrm{~B}$ NMR spectra were recorded with a Varian EM 360 instrument and $\mathrm{SiMe}_{4}$ as internal or $\mathrm{BF}_{3} \mathrm{OEt}_{2}$ as external standard. Mass spectra were recorded with a $\mathrm{CH}-7$ instrument of Atlas, and IR spectra with a Perkin-Elmer 324 spectrometer.

\section{Reaction of $\mathrm{Me}_{2} \mathrm{~B}_{2} \mathrm{~S}_{3}$ with dimethylamine}

a) Ratio $1: 1$

At $-78^{\circ} \mathrm{C} \mathrm{Me}{ }_{2} \mathrm{NH}(1.35 \mathrm{~g}, 30 \mathrm{mmol})$ was condensed into a solution of $\mathrm{Me}_{2} \mathrm{~B}_{2} \mathrm{~S}_{3}(4.44 \mathrm{~g}, 30 \mathrm{mmol})$ in diethyl ether $(30 \mathrm{~mL})$. A white solid formed rapidly which dissolved after warming the suspension to ambient temperature. However, a small amount of a solid $(0.5 \mathrm{~g})$ precipitated from the solution within $6 \mathrm{~h}$. This solid was separated by filtration. From the filtrate about $50 \%$ of the solvent was removed in vacuo. The ${ }^{1} \mathrm{H}$ NMR spectrum showed singlet signals at $0.45,0.88$ and 2.54 and $2.58 \mathrm{ppm}$ (ratio $1: 1: 1: 1$ ), indicating the formation of compound $\mathrm{Me}(\mathrm{SH}) \mathrm{B}-\mathrm{S}-\mathrm{S}-\mathrm{BMe}\left(\mathrm{NMe}_{2}\right)$ with hindered rotation about the BN bond. Further removal of the solvent produced oil-covered crystals $(5.25 \mathrm{~g})$ which became liquid at about $35^{\circ} \mathrm{C}$. Distillation of this material at $70{ }^{\circ} \mathrm{C} / 10^{-3}$ Torr led to $4.2 \mathrm{~g}$ of an oily product which became solid at ambient temperature. Its ${ }^{11} \mathrm{~B}$ NMR spectrum showed the presence of $\mathrm{Me}_{2} \mathrm{~B}_{2} \mathrm{~S}_{3}(\delta=70.7 \mathrm{ppm}, 50 \%)$, and of $\mathrm{Me}_{2} \mathrm{~N}(\mathrm{Me}) \mathrm{BSH}(\delta=$ $42.3 \mathrm{ppm}, 25 \%)$, and a broad signal at $8 \mathrm{ppm}(25 \%)$ most likely due to $\left(\mathrm{Me}_{2} \mathrm{NHB}(\mathrm{Me}) \mathrm{S}_{2}\right)_{2}, \mathbf{1 0}$. The ${ }^{1} \mathrm{H}$ NMR spectrum showed several signals including those of $\mathrm{Me}_{2} \mathrm{~B}_{2} \mathrm{~S}_{3}$ at $1.19 \mathrm{ppm}$ and of $\mathrm{HS}_{2} \mathrm{BMe}-\mathrm{S}-\mathrm{BMe}\left(\mathrm{NMe}_{2}\right)$ at $0.55(3 \mathrm{H})$, $0.95(1 \mathrm{H})$, and $2.75 \mathrm{ppm}(6 \mathrm{H})$, besides signals that could not be reliably assigned at $0.33,0.99,2.3,2.56$ and $2.65 \mathrm{ppm}$. The distillation of this product mixture at $98{ }^{\circ} \mathrm{C} / 10^{-3}$ Torr $(1.33 \mathrm{~g})$ gave a solid fraction with m. p. $84^{\circ} \mathrm{C}$ which according to its ${ }^{1} \mathrm{H}$ NMR spectrum was almost pure $\mathrm{HS}_{2} \mathrm{BMe}-\mathrm{S}$ $\mathrm{BMe}\left(\mathrm{NMe}_{2}\right)$. The distillation residue proved to be a mixture of $\mathrm{Me}_{2} \mathrm{~B}_{2} \mathrm{~S}_{3}(40 \%)$ and $\mathrm{Me}_{2} \mathrm{~N}(\mathrm{Me}) \mathrm{BSH}(60 \%)$, as shown by their ${ }^{1} \mathrm{H}$ NMR signals.

The elemental analysis of the first part of the insoluble material suggested that it consisted mainly of 
compound $\left[\mathrm{MeB}\left(\mathrm{HNMe}_{2}\right) \mathrm{S}_{2}\right]_{2}, \mathbf{1 0}: \mathrm{C}_{6} \mathrm{H}_{20} \mathrm{~N}_{2} \mathrm{~B}_{2} \mathrm{~S}_{2}$ (270.1): calcd. C 26.68, H 7.46, N 10.37; found C 24.26, H 7.26, N 9.22 .

\section{b) Ratio $1: 2$}

As described above, $\mathrm{HNMe}_{2}(2.7 \mathrm{~g}, 60 \mathrm{mmol})$ was condensed into a solution of $\mathrm{Me}_{2} \mathrm{~B}_{2} \mathrm{~S}_{3}(4.44 \mathrm{~g}, 30 \mathrm{mmol})$ dissolved in diethyl ether $(10 \mathrm{~mL})$. A yellowish precipitate formed on warming the mixture to r.t. On heating for $16 \mathrm{~h}$ to reflux most of the solid went into solution. After removal of the solvent distillation at b.p. $40{ }^{\circ} \mathrm{C} / 40$ Torr (redistillation at $52{ }^{\circ} \mathrm{C} / 90$ Torr) yielded $\mathrm{MeB}\left(\mathrm{NMe}_{2}\right) \mathrm{SH}(0.98 \mathrm{~g}$, $32 \%)$ as a colorless moisture-sensitive product. - NMR $\left(\mathrm{CH}_{2} \mathrm{Cl}_{2}\right): \delta^{1} \mathrm{H}=0.55(3 \mathrm{H}), 0.95(1 \mathrm{H}), 2.73(6 \mathrm{H}) \mathrm{ppm}$; $\delta^{11} \mathrm{~B}\left(\mathrm{CH}_{2} \mathrm{Cl}_{2}\right)=42.2 \mathrm{ppm}$. A second fraction obtained at b. p. $28{ }^{\circ} \mathrm{C} / 10$ Torr consisted of $\mathrm{MeB}\left(\mathrm{NMe}_{2}\right) \mathrm{SH}(20 \%)$, and $\mathrm{MeB}\left(\mathrm{NMe}_{2}\right)_{2}\left(\delta^{1} \mathrm{H}=0.16,2.62 \mathrm{ppm}\right.$, ratio $\left.4: 1\right)$. Small signals at $\delta^{1} \mathrm{H}=0.53,0.79,2.78$, and $2.9 \mathrm{ppm}$ may be due to $\mathrm{Me}_{2} \mathrm{NB}(\mathrm{Me})-\mathrm{S}-\mathrm{B}(\mathrm{Me}) \mathrm{NMe}_{2}, 9$.

The non-volatile residue ( $4.5 \mathrm{~g}$ ) was insoluble in chloroform, toluene and THF and could not be characterized.

\section{Reaction of $\mathrm{Me}_{2} \mathrm{~B}_{2} \mathrm{~S}_{3}$ with $\mathrm{HNMe}_{2}$ in the presence of trimethylamine}

To a stirred solution of $\mathrm{Me}_{2} \mathrm{~B}_{2} \mathrm{~S}_{3}(4.44 \mathrm{~g}, 30 \mathrm{mmol})$ in diethyl ether $(60 \mathrm{~mL})$ were condensed at $-78^{\circ} \mathrm{C} \mathrm{NMe}_{3}(3.55 \mathrm{~g}$, $30 \mathrm{mmol})$ and $\mathrm{HNMe}_{2}(2.70 \mathrm{~g}, 30 \mathrm{mmol})$. A slightly yellow precipitate formed which on warming to ambient temperature produced a yellow solution. After removal of the solvent and trimethylamine in vacuo all volatile material of the residue was condensed up to $100^{\circ} \mathrm{C} / 10^{-3}$ Torr. The condensate was recondensed at $100{ }^{\circ} \mathrm{C} / 10^{-3}$ Torr to give a mixture of $2.13 \mathrm{~g}$ of $\mathrm{MeB}\left(\mathrm{NMe}_{2}\right) \mathrm{SH}$ and $\mathrm{MeB}\left(\mathrm{NMe}_{2}\right)_{2}$ (ratio $4: 1) .3 .86 \mathrm{~g}$ of $\left.\left[\left(\mathrm{Me}_{2} \mathrm{NH}\right) \mathrm{MeBSS}\right)\right]_{2}$ remained as a residue, m. p. $158-160{ }^{\circ} \mathrm{C}$. It was characterized by its mass spectrum $\left(\mathrm{m} / \mathrm{z}=270\right.$ calcd. for $\left.{ }^{11} \mathrm{~B}\right)$, its IR spectrum and elemental analysis. $-\mathrm{C}_{6} \mathrm{H}_{20} \mathrm{~N}_{2} \mathrm{~B}_{2} \mathrm{~S}_{2}$ (270.1): calcd. C 26.7, H 7.40, $\mathrm{N} 10.37$; found C 27.22, H 6.95, N 10.45. - IR $\left(\mathrm{cm}^{-1}\right): v=$ 3180 w, 3160 w, 3120 vst (NH), 3030 m, 3000 m, 2960 st, 2960 st, 2930 w, 2895 w, 2825 w, 2760 m, 1455 st, 1450 st, $1422 \mathrm{~m}, 1390$ st, 1309 vst, 1300 vst, 1290 sh, 1270 w, 1130 st, 1013 st, 990 m, 965 st, 945 st, 928 st, 897 st, 800 br, m, 673 st, 645 st, 530 m, 346 m, 270 st, 230 st.

\section{Methyl-phenylmethylamino-sulfhydryl-borane}

A solution of $N$-methylaniline $(6.43 \mathrm{~g}, 60 \mathrm{mmol})$ in diethyl ether $(30 \mathrm{~mL})$ was dropped into a stirred solution of $\mathrm{Me}_{2} \mathrm{~B}_{2} \mathrm{~S}_{3}(4.44 \mathrm{~g}, 30 \mathrm{mmol})$ in diethyl ether $(10 \mathrm{~mL})$ at $-78^{\circ} \mathrm{C}$. On warming to ambient temperature a solid formed which went into solution on heating the mixture to reflux. On cooling to $-20{ }^{\circ} \mathrm{C}$ a solid precipitated which was removed by filtration. The filtrate was subjected to distillation via a Vigreux column. At b. p. $41{ }^{\circ} \mathrm{C} / 10^{-3}$ Torr liquid $\mathrm{Ph}$ MeNB(Me)SH (1.1 g, $21 \%)$ was obtained. All other fractions contained only mixtures of products $\left({ }^{11} \mathrm{~B} \mathrm{NMR}\right)$. $\mathrm{C}_{8} \mathrm{H}_{12} \mathrm{BNS}$ (165.1): calcd. C 58.21, $\mathrm{H} 7.33, \mathrm{~N} 8.48$; found C 59.62, H 7.11, N 8.81. - NMR $\left(\mathrm{C}_{6} \mathrm{D}_{6}\right): \delta^{1} \mathrm{H}=0.54(3 \mathrm{H})$, $1.15(1 \mathrm{H}), 3.1(3 \mathrm{H}), 7.17 \mathrm{ppm}(5 \mathrm{H}) ; \delta^{11} \mathrm{~B}=43.8 \mathrm{ppm}$. IR $\left(\mathrm{cm}^{-1}\right): v=3200(\mathrm{br}), 3060 \mathrm{~m}, 3040 \mathrm{~m}, 2940 \mathrm{st}, 2580 \mathrm{w}$, 1595 vst, 1580 sh, 1490 vst, 1470 st, 1440 st, 1385 vst, 1305 vst, $1280 \mathrm{~m}, 1240$ vst, $1170 \mathrm{w}, 1120 \mathrm{st}, 1095 \mathrm{~m}, 1080 \mathrm{~m}$, 1060 vst, 1040 st, 1020 w, 910 w, 880 w, 860 w, 770 st, 750 st, 969 vst, 620 w, 610 st, 550 st, 540 vst.

\section{Methyl(piperidinyl)-sulfhydryl-borane}

As described above, $\mathrm{Me}_{2} \mathrm{~B}_{2} \mathrm{~S}_{3}(4.44 \mathrm{~g}, 30 \mathrm{mmol})$ was allowed to react with piperidine $(5.11 \mathrm{~g}, 60 \mathrm{mmol})$ in diethyl ether $(30 \mathrm{~mL})$. The precipitate that formed was removed by filtration. Distillation of the filtrate at $29{ }^{\circ} \mathrm{C} / 10^{-2}$ Torr $\left(\mathrm{C}_{5} \mathrm{H}_{10} \mathrm{~N}\right) \mathrm{MeBSH}$ as the only well characterized product $(1.36 \mathrm{~g}, 31.7 \%)$. $-\mathrm{NMR}\left(\mathrm{CH}_{2} \mathrm{Cl}_{2}\right): \delta^{1} \mathrm{H}=0.55(3 \mathrm{H}), 0.84$ $(1 \mathrm{H}), 1.56 \mathrm{ppm}(10 \mathrm{H}) ; \delta^{11} \mathrm{~B}=41.0 \mathrm{ppm}$. $-\mathrm{MS}: \mathrm{m} / z=$ $143\left({ }^{11} \mathrm{~B}\right) .-\mathrm{C}_{6} \mathrm{H}_{14} \mathrm{NBS}(143.06)$, calcd. C 50.38, H 10.04, N 9.77; found C 49.92, H 10.06, N 9.56.

\section{t-Butylamino(t-butyl)-sulfhydryl-borane}

To a stirred solution of $t-\mathrm{Bu}_{2} \mathrm{~B}_{2} \mathrm{~S}_{3}(2.32 \mathrm{~g}, 10 \mathrm{mmol})$ in diethyl ether $(20 \mathrm{~mL})$ was added at $-78{ }^{\circ} \mathrm{C}$ a solution of $t$ $\mathrm{BuNH}_{2}(1.46 \mathrm{~g}, 20 \mathrm{mmol})$ in diethyl ether $(10 \mathrm{~mL})$. The solution was kept at reflux for $24 \mathrm{~h}$. Then the ether was removed by distillation. The residue was fractionally distilled yielding $1.1 \mathrm{~g}(63.5 \%)$ of $t$-BuB(NHt-Bu)(SH) at b. p. $25^{\circ} \mathrm{C} / 8$ Torr. NMR $\left(\mathrm{CH}_{2} \mathrm{Cl}_{2}\right): \delta^{1} \mathrm{H}=0.91(9 \mathrm{H}), 1.28(9 \mathrm{H}), 2.3(1 \mathrm{H})$, $4.3 \mathrm{ppm}(1 \mathrm{H}) ; \delta^{11} \mathrm{~B}=44.5 \mathrm{ppm}$. $-\mathrm{MS}: \mathrm{m} / \mathrm{z}=173\left({ }^{11} \mathrm{~B}\right)$. $\mathrm{C}_{8} \mathrm{H}_{20} \mathrm{NBS}$ (173.13): calcd. C 55.45, H 11.64, N 8.09; found C 55.36, H 11.53, N 7.99.
[1] W. Biffar, H. Nöth, H. Pommerening, R. Schwerthöffer, W. Storch, B. Wrackmayer, Chem. Ber. 1981, $114,49$.

[2] Gmelin Handbook of Inorganic Chemistry. Boron Compounds, $8^{\text {th }}$ Edition, Vol. 19, (Eds.: K. C. Buschbeck, K. Niedenzu), 1975, p. 38.
[3] H. Nöth, W. Reichenbach, W. Winterstein, Chem. Ber. 1977, 110, 2158.

[4] Gmelin Handbook of Inorganic Chemistry. Boron Compounds, $8^{\text {th }}$ Edition, $3^{\text {rd }}$ Supplement, Vol. 3, (Eds.: K. C. Buschbeck, K. Niedenzu), 1988, p. 126.

[5] Gmelin Handbook of Inorganic Chemistry. Boron 
Compounds, $8^{\text {th }}$ Edition, Vol. 22, (Eds.: K. Buschbeck, K. Niedenzu), 1975, p. 299.

[6] Gmelin Handbook of Inorganic Chemistry. Boron Compounds, $8^{\text {th }}$ Edition, $1^{\text {st }}$ Supplement, Vol. 3, (Ed.: K. Niedenzu), 1981, p. 69.

[7] H. Nöth, H. Pommerening, R. Staudigl, Z. Naturforsch. 1988, $43 b, 501$.

[8] For a discussion of B-S $\pi$-bonding, see ref. [1].

[9] H. Nöth, R. Staudigl, R. Brückner, Chem. Ber. 1981, $114,1871$.

[10] R. Johnson, E. Wickoff-Nilsen, H. M. Seip, W. Siebert, Acta Chem. Scan. 1976, 27, 3015.
[11] F. Zettler, S. Politz, J. Forster, H. Hess, Z. Naturforsch. 1988, 31b, 897.

[12] H. Nöth, T. Taeger, Z. Naturforsch. 1979, 34b, 135.

[13] M. Schmidt, W. Siebert, Chem. Ber. 1969, 102, 2752.

[14] A. Meller, C. Habben, Monatsh. Chem. 1984, 113, 939.

[15] F. Riegel, Dissertation, University of Würzburg, Würzburg 1973.

[16] D. Nölle, H. Nöth, T. Taeger, Chem. Ber. 1977, 110, 1643.

[17] H. Vahrenkamp, J. Organomet. Chem. 1971, 28, 167. 